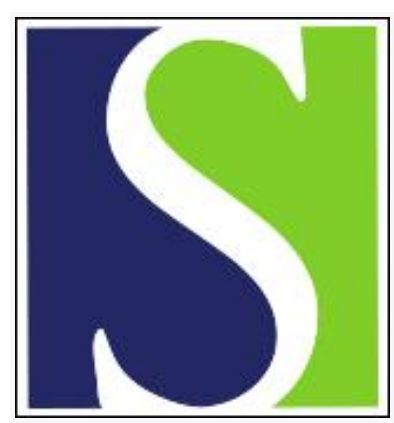

Scand J Work Environ Health 1984;10(4):239-244

https://doi.org/10.5271/sjweh.2335

Issue date: Aug 1984

In vivo study on lead and alcohol interaction and the inhibition of erythrocyte delta-aminolevulinic acid dehydratase in man.

by Telisman S, Prpic-Majic D, Kezic S

This article in PubMed: www.ncbi.nlm.nih.gov/pubmed/6494844 


\title{
In vivo study on lead and alcohol interaction and the inhibition of erythrocyte delta-aminolevulinic acid dehydratase in man'
}

\author{
by Spomenka Telišman, DSc, Danica Prpić-Majić, PhD, Sanja Kežić, MSc²
}

\begin{abstract}
TELIŠMAN S, PRPIĆ-MAJIĆ D, KEŽIĆ S. In vivo study on lead and alcohol interaction and the inhibition of erythrocyte delta-aminolevulinic acid dehydratase in man. Scand $J$ Work Environ Health 10 (1984) $239-244$. The effect on alcohol $(\mathrm{EtOH})$ consumption on the inhibition of erythrocyte $\delta$-aminolevulinic acid dehydratase (ALAD) was investigated in 13 male lead workers and 7 "normal" male subjects. Lead and zinc protoporphyrin in blood and lead, $\delta$-aminolevulinic acid, porphobilinogen and coproporphyrin in 24-h urine specimens were also determined. During $1 \mathrm{~h}$ the subjects drank 122.8 (SD $18.65) \mathrm{ml}$ of an almost lead-free brandy, ie, a dose of $11.07 \mathrm{mmol} / \mathrm{kg}$ of body weight. This dose resulted in a trend toward a parallel decrease in ALAD activity and an increase in lead in blood $(\mathrm{PbB})$, both of which approached the prealcohol value $24 \mathrm{~h}$ after the initial alcohol ingestion. A trend toward increased lead excretion in urine ( $\mathrm{PbU})$ was observed on the day of alcohol ingestion, as compared to the preceding and succeeding 24-h urine specimens. However, the observed increase in $\mathrm{PbB}$ and $\mathrm{PbU}$ cannot be attributed to the small amount of lead ingested through the brandy, ie, 7.09 (SD 1.06) nmol. The characteristic dose-effect relationship between PbB and ALAD (examined prior to and 1, 3, 5, and $24 \mathrm{~h}$ after the initial alcohol ingestion) reached the highest correlation coefficient $3 \mathrm{~h}$ after the initial alcohol ingestion $(\mathrm{p}<0.001)$. The data obtained appear to support the hypothesis of a possible role for the body lead pool and the lead-mediated influence of alcohol consumption on ALAD activity in man.
\end{abstract}

Key terms: biological indicators of lead exposure, biologically active lead deposit, ethanol.

The results of our previous study (17) have indicated that ethanol $(\mathrm{EtOH})$ per se does not inhibit the activity of erythrocyte $\delta$-aminolevulinic acid dehydratase (ALAD) in human blood in vitro. However, it has been confirmed that ALAD activity is readily inhibited by lead. These findings were the basis for the present in vivo study, which was carried out with the same objective: to corroborate the assumption of the possible role of the body lead pool in the inhibition of ALAD activity following alcohol ingestion.

\section{Subjects and methods}

The study was performed with two groups of male volunteers: 13 subjects occupationally exposed to lead ( 7 from a ceramics factory and 6 from a lead products factory) and 7 "normal" subjects nonoccupationally exposed to lead. The subjects were given

\footnotetext{
1 The results of this study were presented at the 20th International Congress on Occupational Health, Cairo, $25 \mathrm{Sep}-$ tember - 1 October 1981 .

2 Institute for Medical Research and Occupational Health, Zagreb, Yugoslavia.
}

Reprint requests to: Dr D Prpić-Majić, Institute for Medical Research and Occupational Health, 158 Moše Pijade, PO Box 291, YU-41001 Zagreb, Yugoslavia.
122.8 (SD 18.65) $\mathrm{ml}$ of Trenk brandy (40 volume/ volume\% EtOH) to drink during a period of $1 \mathrm{~h}$, ie, an ethanol dose of $11.07 \mathrm{mmol} / \mathrm{kg}$ of body weight, which is equivalent to a peak ethanol concentration of approximately $16.28 \mathrm{mmol} / 1$ of blood, known to produce a slightly drunken state (16). Our previous data on blood ethanol determination (after the ingestion of the same dose of Trenk brandy under identical conditions as in the present study) have indicated that a maximal blood ethanol concentration close to $16.28 \mathrm{mmol} / \mathrm{l}$ of blood is reached in the period $1-2 \mathrm{~h}$ after the initial ingestion of the brandy, while it is considerably lowered (to approximately $7.60 \mathrm{mmol} / 1$ blood) in the period $3 \mathrm{~h}$ after the commencement of the experiment (16).

The concentrations of lead and zinc in the brandy were measured with atomic absorption spectrophotometry (AAS) (electrothermal AAS technique for lead and flame AAS technique for zinc). The Trenk brandy contained $57.9 \mathrm{nmol}$ of lead and $4.36 \mu \mathrm{mol}$ of zinc per liter of brandy. Therefore the amount of lead ingested through the brandy corresponded to 7.09 (SD 1.06) nmol of lead, which is a negligible amount if one considers the low lead absorption by the ingestion (about $10 \%$ ) and dilution of lead in the whole body blood volume $(4-5 \mathrm{l})$. The concentration of zinc in the brandy was lower than in tap water. 
Table 1. The prealcohol values and the differences between the post- and prealcohol values of the biological indicators in blood.

\begin{tabular}{|c|c|c|c|c|c|c|c|c|c|c|}
\hline \multirow{3}{*}{ Biological indicator } & \multirow{2}{*}{\multicolumn{2}{|c|}{$\begin{array}{l}\text { Prealcohol value } \\
\text { (Hour 0) } \\
\end{array}$}} & \multicolumn{8}{|c|}{ Difference between post- and prealcohol values } \\
\hline & & & \multicolumn{2}{|c|}{ Hour 1} & \multicolumn{2}{|c|}{ Hour 3} & \multicolumn{2}{|c|}{ Hour 5} & \multicolumn{2}{|c|}{ Hour 24} \\
\hline & Mean & SD & Mean & SD & Mean & SD & Mean & SD & Mean & SD \\
\hline \multicolumn{11}{|l|}{ Lead workers $(N=13)$} \\
\hline Blood lead $\left(\left.\mu \mathrm{mol} \cdot\right|^{-1}\right)$ & 2.778 & 1.079 & -0.054 & 0.531 & 0.102 & 0.440 & -0.114 & 0.766 & -0.191 & 0.610 \\
\hline $\begin{array}{l}\delta \text {-Aminolevulinic acid } \\
\text { dehydratase } \\
{\left[\text { [nmol } \cdot s^{-1} \cdot\left(\text { (Ercs }^{-1}\right]\right.}\end{array}$ & 190.9 & 123.9 & -10.3 & 20.5 & $-22.2^{*}$ & 27.2 & -8.5 & 21.8 & 0.7 & 28.7 \\
\hline $\begin{array}{l}\text { Zinc protoporphyrin } \\
{\left[\mathrm{mmol} \cdot(\mathrm{mol} \mathrm{Hb})^{-1}\right]}\end{array}$ & 0.843 & 0.575 & - & - & - & - & - & - & -0.005 & 0.003 \\
\hline \multicolumn{11}{|c|}{ "Normal" subjects $(N=7)$} \\
\hline Blood lead $\left(\mu \mathrm{mol} \cdot 1^{-1}\right)$ & 1.192 & 0.241 & 0.089 & 0.249 & 0.219 & 0.351 & 0.130 & 0.303 & 0.010 & 0.284 \\
\hline 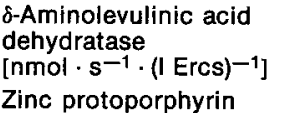 & 795.0 & 296.7 & -21.5 & 85.4 & -195.0 & 240.2 & -206.2 & 236.2 & 11.5 & 18.2 \\
\hline$\left[\mathrm{mmol} \cdot\left(\mathrm{mol} \mathrm{Hb}^{-1}\right]\right.$ & 0.180 & 0.029 & - & - & - & - & - & - & 0.003 & 0.009 \\
\hline
\end{tabular}

* $p<0.02$.

Table 2. The prealcohol values and the differences between the post- and prealcohol values of the biological indicators in 24-h urine specimens, expressed as the quantity excreted per day.

\begin{tabular}{|c|c|c|c|c|c|c|}
\hline \multirow{3}{*}{ Biological indicator } & \multirow{2}{*}{\multicolumn{2}{|c|}{$\begin{array}{l}\text { Prealcohol value } \\
\text { (Day 0) }\end{array}$}} & \multicolumn{4}{|c|}{ Difference between post- and prealcohol value } \\
\hline & & & \multicolumn{2}{|c|}{ Day 1} & \multicolumn{2}{|c|}{ Day 2} \\
\hline & Mean & SD & Mean & SD & Mean & SD \\
\hline \multicolumn{7}{|l|}{ Lead workers $(N=13)$} \\
\hline Urinary lead (nmol $\left.\cdot d^{-1}\right)$ & 310 & 305 & 64 & 220 & -110 & 204 \\
\hline $\begin{array}{l}\text { Urinary } \delta \text {-aminolevulinic acid } \\
\left(\mu \mathrm{mol} \cdot \mathrm{d}^{-1}\right)\end{array}$ & 116 & 149 & -15 & 126 & -21 & 97 \\
\hline $\begin{array}{l}\text { Urinary porphobilinogen } \\
\left(\mathrm{nmol} \cdot \mathrm{d}^{-1}\right)\end{array}$ & 4,005 & 4,023 & $-1,206$ & 3,852 & $-1,661$ & 3,070 \\
\hline Urinary coproporphyrin $\left(\mathrm{nmol} \cdot \mathrm{d}^{-1}\right)$ & 674 & 870 & -264 & 635 & $-383^{*}$ & 599 \\
\hline Urine volume $\left(\mathrm{ml} \cdot \mathrm{d}^{-1}\right)$ & 1,054 & 327 & -142 & 323 & -96 & 461 \\
\hline \multicolumn{7}{|l|}{ "Normal" subjects $(N=7)$} \\
\hline Urinary lead $\left(\mathrm{nmol} \cdot \mathrm{d}^{-1}\right)$ & 55 & 15 & $22^{* *}$ & 17 & 1 & 40 \\
\hline $\begin{array}{l}\text { Urinary } \delta \text {-aminolevulinic acid } \\
\left(\mu \mathrm{mol} \cdot \mathrm{d}^{-1}\right)\end{array}$ & 21 & 10 & 9 & 12 & 8 & 11 \\
\hline Urinary porphobilinogen $\left(\mathrm{nmol} \cdot \mathrm{d}^{-1}\right)$ & 2,414 & 1,139 & 969 & 1,152 & 752 & 1,654 \\
\hline Urinary coproporphyrin $\left(\mathrm{nmol}^{-} \mathrm{d}^{-1}\right)$ & 145 & 57 & 35 & 101 & $-24^{* *}$ & 18 \\
\hline Urine volume $\left(\mathrm{ml} \cdot \mathrm{d}^{-1}\right)$ & 1,071 & 357 & 193 & 343 & 264 & 339 \\
\hline
\end{tabular}

* $p<0.05,{ }^{* *} p<0.02$

Table 3. The prealcohol values and the differences between the post- and prealcohol values of the biological indicators in 24-h urine specimens, expressed as the quantity per liter of urine.

\begin{tabular}{|c|c|c|c|c|c|c|}
\hline \multirow{3}{*}{ Biological indicator } & \multirow{2}{*}{\multicolumn{2}{|c|}{$\begin{array}{l}\text { Prealcohol value } \\
\text { (Day 0) }\end{array}$}} & \multicolumn{4}{|c|}{ Difference between post- and prealcohol value } \\
\hline & & & \multicolumn{2}{|c|}{ Day 1} & \multicolumn{2}{|c|}{ Day 2} \\
\hline & Mean & SD & Mean & SD & Mean & SD \\
\hline \multicolumn{7}{|l|}{ Lead workers $(N=13)$} \\
\hline Urinary lead $\left(\left.\mathrm{nmol} \cdot\right|^{-1}\right)$ & 262 & 222 & $115^{*}$ & 176 & -80 & 159 \\
\hline $\begin{array}{l}\text { Urinary } \delta \text {-aminolevulinic acid } \\
(\mu \mathrm{mol} \cdot(-1)\end{array}$ & 103 & 114 & 7 & 73 & -20 & 69 \\
\hline $\begin{array}{l}\text { Urinary porphobilinogen } \\
\left(\left.\mathrm{nmol} \cdot\right|^{-1}\right)\end{array}$ & 3,545 & 2,864 & -746 & 2,931 & $-1,026$ & 2,727 \\
\hline Urinary coproporphyrin $\left(\left.\mathrm{nmol} \cdot\right|^{-1}\right)$ & 632 & 854 & -183 & 636 & -329 & 586 \\
\hline \multicolumn{7}{|l|}{ "Normal" subjects $(N=7)$} \\
\hline Urinary lead $\left(\mathrm{nmol} \cdot \mathrm{I}^{-1}\right)$ & 54 & 4 & 10 & 12 & -13 & 20 \\
\hline $\begin{array}{l}\text { Urinary } \delta \text {-aminolevulinic acid } \\
\left(\left.\mu \mathrm{mol} \cdot\right|^{-1}\right)\end{array}$ & 21 & 9 & 3 & 10 & 2 & 11 \\
\hline Urinary porphobilinogen $\left(\left.\mathrm{nmol}^{-1}\right|^{-1}\right)$ & 2,166 & 688 & 433 & 675 & 260 & 1,154 \\
\hline Urinary coproporphyrin (nmol $\left.\cdot \mathrm{I}^{-1}\right)$ & 137 & 46 & 7 & 49 & $-39^{* *}$ & 32 \\
\hline
\end{tabular}

* $p<0.05,{ }^{* *} p<0.02$. 
In both groups of subjects, the ALAD activity (2) and lead in blood $(\mathrm{PbB})(7)$ were determined immediately before the ingestion of the brandy (hour 0 ) and at 1-, 3-, 5-, and 24-h intervals after the first measurement. The concentration of zinc protoporphyrin $(\mathrm{ZnPP})$ in blood (3) was measured before the brandy ingestion and $24 \mathrm{~h}$ later. Urine (a 24-h specimen) was collected on three consecutive days, ie, a day before brandy consumption (day 0 ), on the day of consumption (day 1), and the day after consumption (day 2). An extra precaution was taken to ensure the correct collection of 24-h urine specimens. (The lead workers were hospitalized in our department and were under continuous control during the period of investigation, while the "normal" subjects were our colleagues from the Institute and were fully aware of the problem.) In each urine specimen the concentrations of lead (PbU) (24), $\delta$-aminolevulinic acid (ALAU) (6), porphobilinogen (PBGU) (12), and coproporphyrin (CPU) (23) were measured. The dithizone method used for determining PbU (24) was modified for the urine analysis, ie, by an increase in the sample volume ( $50 \mathrm{ml}$ of urine), a gradual addition of nitric acid (5-ml aliquots), and the calibration performed for the urine. The precision of the applied methods, expressed as a relative standard deviation (CV), was $\leq 5 \%$ for $\mathrm{PbB}, \leq 2 \%$ for ALAD, $\leq 5 \%$ for $\mathrm{ZnPP}, \leq 4 \%$ for PbU, ALAU and PBGU, and $\leq 5 \%$ for CPU. All the analyses were performed in duplicate, and the mean values were used for the calculations.

The results of the biological indicators following alcohol ingestion were compared to prealcohol values, and the significance of the difference was tested by Student's t-test (ie, $t=\bar{X}_{\text {diff }} / \mathrm{SE}_{\text {diff }}$ ). Due to the possible influence of diuresis, the data on the urinary indicators (PbU, ALAU, PBGU, CPU) have been expressed both in terms of daily excretion (quantity excreted per day) and the concentration (quantity per liter of urine).

\section{Results}

The data on the simultaneous determination of the biological indicators of lead absorption (PbB, ALAD, ZnPP, PbU, ALAU, PBGU, CPU), measured before alcohol consumption and at different periods following alcohol ingestion (expressed as the difference between post- and prealcohol values), are presented in tables $1-3$.

The relative changes in ALAD and $\mathrm{PbB}$, expressed as the ratio between the post- and prealcohol values, are shown in figure 1. These data indicate that the ingestion of the alcoholic beverage resulted in a depression of ALAD activity and a parallel increase in $\mathrm{PbB}$. The change in both parameters appeared to reach a maximum in the period $3 \mathrm{~h}$ after the initial alcohol ingestion. Both $\mathrm{PbB}$ and $\mathrm{ALAD}$ approached the prealcohol value $24 \mathrm{~h}$ after the initial alcohol ingestion.

Due to the small number of subjects and considerable inter- and intraindividual variations in diuresis after alcohol consumption, eg, decreased diuresis in lead workers and increased diuresis in "normal" subjects (table 2), the results concerning the urinary indicators are expressed as the quantity per liter of urine (table 3) for a better comparison of the data of both groups. These data indicate an increase in $\mathrm{PbU}$ on the day of alcohol ingestion (day 1), as compared to preceding and succeeding 24-h urine specimens. However, although an identical dose of alcoholic beverage was given (providing a comparable increase in both $\mathrm{EtOH}$ and $\mathrm{Pb}$ ), the increase in $\mathrm{PbU}$ appeared to be considerably more pronounced for the lead workers as compared to the "normal" subjects.

The semilogarithmic dose-effect relationship between $\mathrm{PbB}$ and ALAD was highly significant $(\mathrm{p}<0.001)$ for all the examined intervals, ie, log ALAD/lin PbB $(\mathrm{N}=20): \mathrm{r}_{0}=-0.878, \mathrm{r}_{1}=$ $-0.817, \mathrm{r}_{3}=-0.887, \mathrm{r}_{5}=-0.751, \mathrm{r}_{24}=-0.826$. However, for certain periods, the relationship was less significant within the group of lead workers $(\mathrm{N}=13): \mathrm{r}_{0}=-0.801,(\mathrm{p}<0.001), \mathrm{r}_{1}=-0.681$ $(\mathrm{p}<0.02), \mathrm{r}_{3}=-0.855(\mathrm{p}<0.001), \mathrm{r}_{5}=-0.549$ $(p>0.05), r_{24}=-0.655(p<0.02)$, and not significant at all $(\mathrm{p}>0.10)$ within the group of "normal" subjects $(\mathrm{N}=7)$. The highest correlation coefficient ( $r$ ) was recorded $3 \mathrm{~h}$ after the initial alcohol ingestion. The relationship between $\mathrm{PbB}$ and ALAD for lead workers and for the pooled data of both groups is presented for the period immediately before alcohol ingestion (figure 2), $3 \mathrm{~h}$ later (figure 3), and $24 \mathrm{~h}$ after the first measurement (figure 4). The differences in dose-effect relationship between $\mathrm{PbB}$ and ALAD with respect to alcohol consumption appear to support the hypothesis that the changes in both parameters reflect the alcohol-induced redistribution between the "stable" and the "mobile" lead frac-

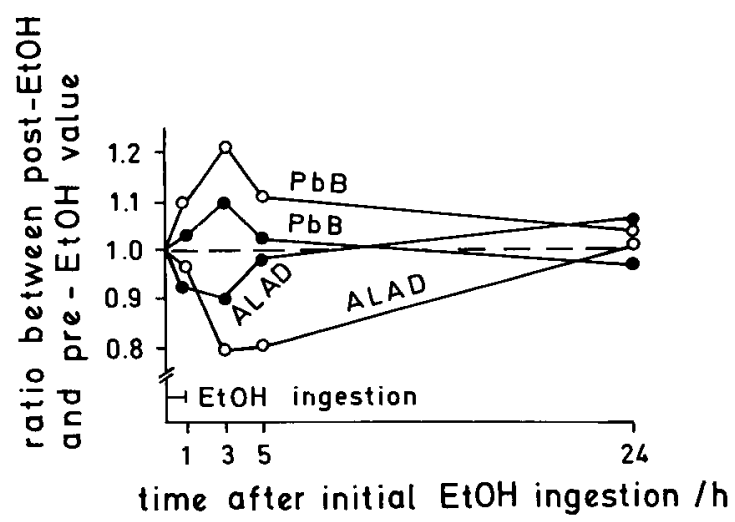

Figure 1. The relative changes in erythrocyte $\delta$-aminolevulinic acid dehydratase (ALAD) and lead in blood (PbB) following alcohol (EtOH) ingestion, expressed as the mean values of the ratio between the post- and prealcohol value of lead workers (O) and "normal" subjects $(O)$. 


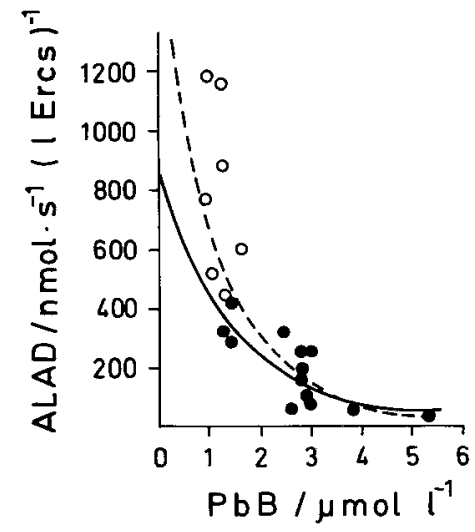

Figure 2. Dose-effect relationship between lead in blood (PbB) and erythrocyte $\delta$-aminolevulinic acid dehydratase (ALAD) of lead workers (O) and "normal" subjects (O) immediately before alcohol ingestion. The relationship for 13 lead workers $(-)$ : $\log A L A D=2.929-0.278 \mathrm{PbB}, r=-0.801$, $p<0.001$; the relationship for all 20 subjects examined $(--)$ : $\log \mathrm{ALAD}=3.196-0.356 \mathrm{PbB}, r=-0.878, \mathrm{p}<0.001$.

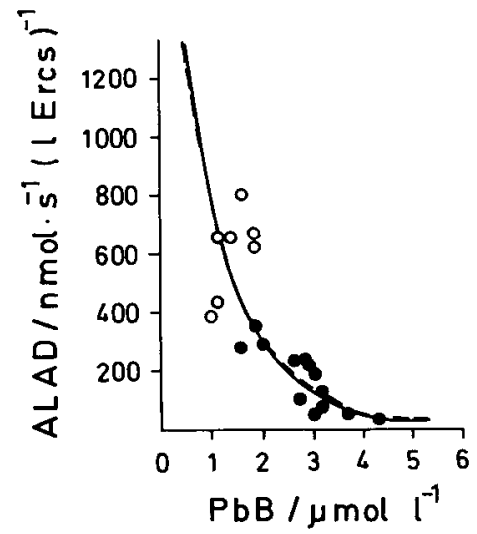

Figure 3. Dose-effect relationship between lead in blood (PbB) and erythrocyte $\delta$-aminolevulinic acid dehydratase (ALAD) of lead workers (0) and "normal" subjects (O) $3 \mathrm{~h}$ after the initial alcohol ingestion. The relationship for 13 lead workers (-): $\log A L A D=3.309-0.418 \mathrm{PbB}, r=-0.855$, $p<0.001$; the relationship for all 20 subjects examined $(--)$ : $\log A L A D=3.303-0.408 \quad \mathrm{PbB}, \quad r=-0.887, \quad \mathrm{p}<0.001$.

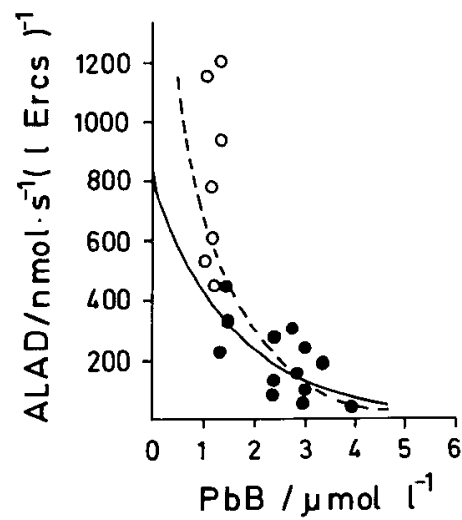

Figure 4. Dose-effect relationship between lead in blood (PBB) and erythrocyte $\delta$-aminolevulinic acid dehydratase (ALAD) of lead workers (O) and "normal" subjects (O) $24 \mathrm{~h}$ after the initial alcohol ingestion. The relationship for 13 lead workers (-): $\log$ ALAD $=2.913-0.286 \mathrm{PbB}, r=-0.655$. $p<0.02$; the relationship for all 20 subjects examined $(\cdots)$ : $\log A L A D=3.267-0.402 \mathrm{PbB}, r=-0.826, p<0.001$. tions of the total body lead pool in favor of the "mobile" (biologically active) fraction, with subsequent partial excretion of the mobilized lead.

\section{Discussion}

The present data indicate the possibility of a leadmediated influence of alcohol consumption on the inhibition of erythrocyte ALAD activity in man. This phenomenon is seen in the trend towards increasing $\mathrm{PbB}$, occurring in parallel with a decrease in ALAD, in a lead-exposed and "normal" group following alcohol ingestion (figure 1). Moreover, the doseeffect relationship between $\mathrm{PbB}$ and $\mathrm{ALAD}$ reached the highest correlation coefficient at a time when the highest blood ethanol concentrations were no longer expected (16) but the lowest ALAD activity and the highest $\mathrm{PbB}$ values were observed. In addition an increase in $\mathrm{PbU}$ was found in both groups on the day of alcohol ingestion, as compared to preceding and succeeding 24-h urine specimens (tables $2 \& 3$ ). Since the observed increase in $\mathrm{PbB}$ and $\mathrm{PbU}$ cannot be attributed to the relatively negligible intake of lead through the brandy, the possibility of an alcoholinduced interchange between the "stable" and "mobile" lead fractions of the total body lead pool (eg, through alcohol-induced alterations in the tissue redox potential) should be taken into consideration.

With regard to the application of ALAD as a biological indicator of lead exposure (absorption), the influence of alcohol consumption on erythrocyte ALAD in man was usually interpreted as an interference which decreases the specificity of ALAD for lead. A significant negative correlation between the ALAD and ethanol levels in the blood was found for patients intoxicated with alcohol (15). However, no significant correlation between ALAD and ethanol has been found by other authors $(9,11)$. A decrease of erythrocyte ALAD has often been associated with an increase of $\mathrm{PbB}(11,14,22)$, and highly significant correlations between ALAD and PbB have also been reported $(11,22)$. Clinical experience has indicated that alcohol consumption may be a predisposing factor for lead poisoning $(4,5)$. In addition to decreased levels of $\mathrm{ALAD}$, the findings reported with respect to alcohol consumption (13) appear to resemble closely the characteristic effects of lead.

The decreased ALAD levels found to be associated with alcohol consumption can be due to increased lead intake (through lead-contaminated alcoholic beverages) and/or increased lead mobilization (ie, activation of the "stable," biologically inert lead fraction of the total body lead pool) with a transient increase in the bone marrow lead, and in $\mathrm{PbB}$, and subsequent partial excretion. Since the former possibility is indisputable, with regard to the latter possibility, it is interesting to note that even slightly higher than average "normal" ALAD values were found in chronic alcoholics during the inactive phase $(10,11)$. 
The latter possibility might partly explain why the observed increase of $\mathrm{PbB}$ with respect to alcohol consumption in an urban population could not be ascribed to any particular form of alcoholic beverage (ie, to the differences in lead content), but rather the total alcohol intake seems to be relevant $(8,19)$. It might also explain why a significant increase in $\mathrm{PbB}$ $(\mathrm{r}=0.296, \mathrm{p}<0.02)$ and a decrease in ALAD $(\mathrm{r}=$ $-0.255, \mathrm{p}<0.05$ ) was found with respect to the age of 66 patients with nonalcoholic liver disease, and an opposite trend with respect to age (although not significant) was found for both $\mathrm{PbB}(\mathrm{r}=-0.029)$ and ALAD $(r=0.118)$ for 211 patients with alcoholic liver disease. ${ }^{3}$ In both groups highly significant $(p<0.001)$ correlations between ALAD and PbB were found $(\mathrm{r}=-0.408$ for nonalcoholics and $\mathrm{r}=$ -0.516 for alcoholics). However, even the lack of a significant correlation between ALAD and PbB (14) should not automatically exclude the possible role of lead in the depression of ALAD activity. It has been shown that $\mathrm{PbB}$ mainly reflects the current (recent) lead exposure level, while ALAD better reflects the integrated (long-term) lead exposure and the biologically active lead deposit $(1,20,21)$. Therefore the possible influence of alcohol consumption via a biologically active lead deposit, which is less reflected by $\mathrm{PbB}$ than by ALAD, can even be regarded as a possible explanation for such findings.

In conclusion, the present results indicate that data on the specificity of ALAD for lead, ie, interference of other factors on ALAD activity in vivo, should be interpreted with caution. However, the reported influence of, eg, alcohol consumption $(10,14,15)$ or smoking (18) on the depression of ALAD activity in man might also be explained via a biologically active lead deposit, less reflected by PbB than by ALAD.

\section{References}

1. Alessio L, Castoldi MR, Odone P, Franchini I. Behaviour of indicators of exposure and effect after cessation of occupational exposure to lead. $\mathrm{Br} \mathbf{J}$ Ind Med 38 (1981) 262-267.

2. Berlin A, Schaller KH. European standardized method for the determination of $\delta$-aminolevulinic acid dehydratase activity in blood. $\mathrm{Z}$ klin Chem klin Biochem 12 (1974) 389-390.

3. Blumberg WE, Eisinger J, Lamola AA, Zuckerman DM. Zinc protoporphyrin level in blood determined by a portable hematofluorometer: A screening device for lead poisoning. J Lab Clin Med 89 (1977) 712-723.

4. Cardani A, Farina G. Influenza del consumo di bevande alcoholice sulle alterazione della biosintesi dell'eme indotte dal piombo. Med Lav 63 (1972) $22-28$.

3 According to an unpublished paper by A Bortoli, G Mattiello, G Trabuio \& S Zotti (Laboratorio d'Igiene e Profilassi, Sezione Chimica, Venice, Italy) entitled "Blood Lead Levels and ALA-D Activity versus Age in Patients with Liver Disease," which was presented by Dr G Mattiello at the International Conference on Heavy Metals in the Environment, Amsterdam, 15-18 September 1981.
5. Cramer K. Predisposing factors for lead poisoning. Acta Med Scand Suppl 445 (1966) 56-59.

6. Davis JR, Andelman SL. Urinary delta-aminolevulinic acid levels in lcad poisoning: A modified method for the rapid determination of urinary delta-aminolevulinic acid using disposable ion-exchange chromatography columns. Arch Environ Health 15 (1967) 53-59.

7. Fernandez FJ. Micromethod for lead determination in whole blood by atomic absorption, with use of the graphite furnace. Clin Chem 21 (1975) 558-561.

8. Grandjean P, Olsen NB, Hollnagel H. Influence of smoking and alcohol consumption on blood lead levels. Int Arch Occup Environ Health 48 (1981) 391-397.

9. Hamlyn AN, Hopper JC, Skillen AW. Assessment of erythrocyte $\delta$-aminolevulinate dehydratase for outpatient detection of alcoholic liver disease: Comparison with $\gamma$-glutamyltransferase and casual blood ethanol. Clin Chim Acta 95 (1979) 453-459.

10. Krasner N, Moore MR, Thompson GG, McIntosh W, Goldberg A. Depression of erythrocyte $\delta$-aminolaevulinic acid dehydratase activity in alcoholics. Clin Sci Mol Med 46 (1974) 415-418.

11. Magid E, Hilden M. Elevated levels of blood lead in alcoholic liver disease. Int Arch Occup Health 35 (1975) 61-65.

12. Mauzerall D, Granick S. The occurrence and determination of $\delta$-aminolevulinic acid and porphobilinogen in urine. J Biol Chem 219 (1956) 435-446.

13. McColl KEL, Thompson GG, Moore MR, Goldberg A. Acute ethanol ingestion and haem biosynthesis in healthy subjects. Eur J Clin Invest 10 (1980) 107-112.

14. Moore MR. Lead ethanol and $\delta$-aminolaevulinic acid dehydratase. In: Commission of the European Communities. Proceedings of the International Symposium on the Recent Advances in the Assessment of the Health Effects of Environmental Pollution, Paris June $24-28,1974$. Volume II. Luxembourg 1975, pp $1171-1176$.

15. Moore MR, Beattie AD, Thompson GG, Goldberg A. Depression of $\delta$-aminolaevulinic acid dehydratase activity by ethanol in man and rat. Clin Sci 40 (1971) $81-88$.

16. Prpić-Majić D, Beritić $T$, Panjkota V, Keršanc $A$, Karačić V. Studies on toxic porphyria: II The influence of ethanol on ALA-D activity in lead poisoning. Arch Hig Rada Toksikol 23 (1972) 215-223.

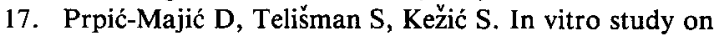
lead and alcohol interaction and the inhibition of erythrocyte delta-aminolevulinic acid dehydratase in man. Scand J Work Environ Health 10 (1984) 235238.

18. Salle HJA, Zielhuis RL. Influence of smoking on aminolevulinic acid dehydratase activity, haematocrite and lead in blood in adult urban women. Int Arch Occup Environ Health 40 (1977) 111-145.

19. Shaper AG, Pocock SJ, Walker M, Wale CJ, Clayton B, Delves HT, Hinks L. Effects of alcohol and smoking on blood lead in middle-aged British men. $\mathrm{Br}$ Med J 284 (1982) 299-302.

20. Telišman S, Keršanc A, Prpić-Majić D. The relevance of arguments for excluding ALAD from the recommended biological limit values in occupational exposure to inorganic lead (WHO 1980). Int Arch Occup Environ Health 50 (1982) 397-412.

21. Telišman $S$, Prpić-Majić $D$. The relative applicability of $\mathrm{PbB}, \mathrm{ALAD}$ and EP in the assessment of external exposure and health effect of inorganic lead. In: CEP Consultants Ltd. Proceedings of the International Conference on Management \& Control of Heavy Metals in the Environment, London Sept 18-21, 1979. Edinburgh 1979, pp 62-65. 
22. Vives JF, Bellet $\mathbf{H}$, Lapinski $\mathbf{H}$, Mirouze D, Richard JL, Hirsch JL, Soulayrac M, Mathieu-Daude P, Vallat $\mathrm{G}$, Michel H. Alcoolisme chronique et intoxication saturnine. Gastroenterol Clin Biol 4 (1980) 119-122.

23. Weber K, Valić F. Die Fluorometrie im Dienste der medizinischen Chemie. Arh Hig Rada Toksikol 8 (1957) 39-60.
24. Weber OA, Voloder K, Vouk VB. Determination of lead in blood. Arh Hig Rada 3 (1952) 296-313.

Received for publication: 14 March 1984 